\title{
Gynecologic and Obstetric Investigation
}

Founded 1895 as 'Monatsschrift für Geburtshilfe und Gynäkologie', continued 1946-1969 as 'Gynaecologia' and 1970-1977 as 'Gynecologic Investigation'

\section{Editor-in-Chief}

T.M. D’Hooghe, Leuven
Founders: A. Martin and M. Sänger

Former Editors: E. Anderes (1939-1952), Th. Koller (1939-1969), O. Käser (1954-1969),

R. Wenner (1959-1967), P. Bloch (1965-1969), W.L. Hermann (1970-1975),

P.J. Keller (1976-1984), G. Zador (1985-2001), J. Yankowitz (2002-2005)

\section{Associate Editors}

Benign Gynecological Disease/

Gynecological Surgery

A.D. Ebert, Berlin

Clinical Obstetrics

Edgar Hernandez-Andrade,

Detroit, Mich.

Early Pregnancy and

Recurrent Miscarriage

Ole B. Christiansen, Copenhagen

Fetal Medicine/Surgery

Roland De Vlieger, Leuven

Gynecologic Oncology

Christina Bandera, Cranston, R.I.
Gynecological Ultrasound and Imaging George Condous, St. Leonards, N.S.W.

Infectious Diseases

Gilbert G.G. Donders, Leuven

Menopause, Contraception and

General Gynecologic Endocrinology

Serge Rozenberg, Brussels

Prenatal Diagnosis

Waldo Sepulveda, Santiago

Psychology, Sexuology and

Mental Health

Jacky Boivin, Cardiff

Reproductive Genetics

Zi-Jiang Chen, Jinan
Reproductive Immunology

Aydin Arici, New Haven, Conn.

Reproductive Surgery

Togas Tulandi, Montreal, Que.

Society/Ethics/History

I. D. Cooke, Sheffield

Urogynecology

Jan-Paul Roovers, Amsterdam

\section{Editorial Board}

\section{M.A. Belfort, Provo, Utah}

J. Bornstein, Nahariya

H.L. Brown, Durham, N.C.

C. Chapron, Paris

J. de Haan, Maastricht

G.A. Dekker, Adelaide, S.A.

J.A. Deprest, Leuven

K. Hecher, Hamburg

S. Kahhale, São Paulo

H. Kliman, New Haven, Conn.
T.F. Kruger, Tygerberg

J.A. Kuller, Raleigh, N.C.

M.J. Kupferminc, Tel Aviv

H. Minkoff, Brooklyn, N.Y.

J. Moodley, Congella

J.M. Mwenda, Nairobi

H. Odendaal, Tygerberg

J.T. Repke, Hershey, Pa.

G.R. Saade, Galveston, Tex.

B.M. Sibai, Cincinnati, Ohio
S.K. Smith, London

I.E. Timor-Tritsch, New York, N.Y.

S. Uzan, Paris

Johan Verhaeghe, Leuven

J.J. Walker, Leeds

G.D. Wendel, Dallas, Tex.

R.A. Wild, Oklahoma City, Okla.

G. Zador, Södertälje

M.B. Zimmerman, Iowa City, Iowa 
S. Karger

Medical and Scientific Publishers

Basel • Freiburg • Paris • London • New York •

New Delhi • Bangkok • Beijing • Tokyo •

Kuala Lumpur $\cdot$ Singapore $\cdot$ Sydney
Disclaimer

The statements, opinions and data contained in this publication are solely those of the individual authors and contributors and not of the publisher and the editor(s). The appearance of advertisements in the journal is not a warranty, endorsement, or approval of the products or services advertised or of their effectiveness, quality or safety. The publisher and the editor(s) disclaim responsibility for any injury to persons or property resulting from any ideas, methods, instructions or products referred to in the content or advertisements.

Drug Dosage

The authors and the publisher have exerted every effort to ensure that drug selection and dosage set forth in this text are in accord with current recommendations and practice at the time of publication. However, in view of ongoing research, changes in government regulations, and the constant flow of information relating to drug therapy and drug reactions, the reader is urged to check the package insert for each drug for any change in indications and dosage and for added warnings and precautions. This is particularly important when the recommended agent is a new and/or infrequently employed drug.
All rights reserved.

No part of this publication may be translated into other languages, reproduced or utilized in any form or by any means electronic or mechanical, including photocopying, recording microcopying, or by any information storage and retrieval system, without permission in writing from the publisher or system, without permission in writing from the publisher or,
in the case of photocopying, direct payment of a specified fee to the Copyright Clearance Center (see 'General Information')

(c) Copyright $2012 / 2013$ by S. Karger AG,

CH-4009 Basel (Switzerland)

Printed in Switzerland

on acid-free and non-aging paper (ISO 9706) by

Reinhardt Druck, Basel

\section{KARGER}


Gynecologic and

Obstetric Investigation

No. 1

Review

1 Laparoscopic Cervicoisthmic Cerclage: Technique and Systematic Review of the Literature

El-Nashar, S.A. (Assiut); Paraiso, M.F.; Rodewald, K.; Muir, T.

(Cleveland, Ohio); AbdelHafez, F. (Assiut/Cleveland, Ohio); Lazebnik, N.

(Cleveland, Ohio); Bedaiwy, M.A. (Assiut/Cleveland, Ohio)

Original Articles

9 Gonadotropin-Releasing Hormone Analogues Reduce the Proliferation of Endometrial Stromal Cells but Not Endometriotic Cells

Taniguchi, F.; Higaki, H.; Azuma, Y.; Deura, I.; Iwabe, T.; Harada, T.; Terakawa, N. (Yonago)

16 Single-Port Access Total Laparoscopic Hysterectomy for Large Uterus

Song, T.; Lee, Y.; Kim, M.-L.; Yoon, B.S.; Joo, W.-D.; Seong, S.J;; Kim, I.H. (Seoul)

21 Tissue Composition of the Vaginal Wall in Women with Pelvic Organ Prolapse

Meijerink, A.M.; van Rijssel, R.H.; van der Linden, P.J.Q. (Deventer)

28 Volume-Related Measurement Error by Three-Dimensional Ultrasound with a Rotational Multiplanar Technique Smeets, N.A.C. (Parkstad); Winkens, B. (Maastricht); Oei, S.G. (Veldhoven)

34 Role of Pelvic Floor Muscle Exercises in the Prevention of Stress Urinary Incontinence during Pregnancy and the Postpartum Period Kocaöz, S. (Niğde); Eroğlu, K.; Sivaslıŏlu, A.A. (Ankara)

41 The K-P Algorithm: A New First-Trimester Growth Model Comparison with Other Formulae and Correlations with Recorded Embryonic Lengths

Mongelli, M.; Riemke, J.; Casikar, I.; Alhamdan, D.; Benzie, R.; Condous, G. (Penrith, N.S.W.)

46 Comparison of the Effects of Electrical Stimulation and Posterior Tibial Nerve Stimulation in the Treatment of Overactive Bladder Syndrome

Gungor Ugurlucan, F.; Onal, M.; Aslan, E.; Ayyildiz Erkan, H.; Kizilkaya Beji, N.; Yalcin, O. (Istanbul)

53 Characterization of Sociodemographic and Clinicopathological Features in Brazilian Patients with Vulvar Squamous Cell Carcinoma

de Melo Maia, B.; Munhoz Cestari, F.; Lavorato-Rocha, A.M.;

Sant’Ana Rodrigues, I.; Baiocchi, G.; Cardoso Guimarães, G. (São Paulo);

Vassallo, J. (São Paulo /Campinas); Stiepcich, M.; Soares, F.A.; Malagoli Rocha, R. (São Paulo)

61 Association between Hysterectomy with Ovarian Preservation and Cardiovascular Disease in a Norwegian Population-Based Sample

Michelsen, T.M. (Oslo/Arendal); Dørum, A.; Cvancarova, M. (Oslo); Liavaag, A.H. (Arendal); Dahl, A.A. (Oslo)

68 Expression of ER- $\alpha 36$, a Novel Variant of Estrogen Receptor in Endometrial Carcinoma and Its Clinical Significance Sun, L.; Wang, J.; Zhang, L.; Li, X.; Shen, D. (Beijing)
No. 2

Review

73 Female Gender and Reproductive Factors Affecting Risk, Relapses and Progression in Multiple Sclerosis

D'hooghe, M.B. (Melsbroek/Brussels); D’Hooghe, T. (Leuven); De Keyser, J. (Brussels/Groningen)

Original Articles

85 Biomechanical Properties of Vaginal Tissue in Women with Pelvic Organ Prolapse

Martins, P. (Porto); Lopes Silva-Filho, A.; Rodrigues Maciel da Fonseca, A.M. (Belo Horizonte); Santos, A.; Santos, L. (Porto/Lisbon); Mascarenhas, T.; Natal Jorge, R.M.; Ferreira, A.J.M. (Porto)

93 Vaginoplasty Using Acellular Porcine Small Intestinal Submucosa Graft in Two Patients with Meyer-von-RokitanskyKüster-Hauser Syndrome: A Prospective New Technique for Vaginal Reconstruction

Ding, J.-X.; Zhang, X.; Chen, L.; Hua, K.-Q. (Shanghai)

97 Intermenstrual Pelvic Pain, Quality of Life and Mood Grandi, G.; Xholli, A.; Ferrari, S.; Cannoletta, M.; Volpe, A.; Cagnacci, A. (Modena)

101 Intrapartum Heart Rate Ambiguity: A Comparison of Cardiotocogram and Abdominal Fetal Electrocardiogram with Maternal Electrocardiogram

Reinhard, J. (Frankfurt am Main); Hayes-Gill, B.R. (Nottingham); Schiermeier, S.; Hatzmann, H. (Witten); Heinrich, T.M.; Louwen, F. (Frankfurt am Main)

109 Short-Term Effects of High-Dose Khat on Sperm Parameters and Reproductive Hormonal Levels in Olive Baboons (Papio anubis)

Nyachieo, A.; Kiraithe, M.M. (Nairobi); Spiessens, C. (Leuven); Chai, D.C.; Kiulia, N.M. (Nairobi); D’Hooghe, T.M. (Nairobi/Leuven); Mwenda, J.M. (Leuven)

115 Treatment Options To Terminate Persistent Cesarean Scar Pregnancy

Zhang, Y.; Duan, H.; Cheng, J.-M.; Guo, Y.-S. (Beijing)

120 Three-Dimensional Angioultrasonography for the Prediction of Malignancy in Ovarian Masses

Perez-Medina, T.; Orensanz, I.; Pereira, A.; Valero de Bernabé, J.; Engels, V. Troyano, J.; SanFrutos, L.; Iglesias, E. (Madrid)

126 Aquaglyceroporin-7 Overexpression in Women with the Polycystic Ovary Syndrome

Seow, K.-M. (Taipei); Lin, Y.-H. (Taipei/Taipei Hsien); Wang, P.-H.; Hwang, J.-L.; Ho, L.-T.; Juan, C.-C. (Taipei)

Novel Insights from Clinical Practice

132 Large Pancreatic Mucinous Cystic Neoplasm during Pregnancy: What Should Be Done?

Tica, A.A.; Tica, O.S.; Saftoiu, A.; Camen, D. (Craiova); Tica, V.I. (Constanta)

\section{KARGER}

E-Mail karger@karger.com www.karger.com
(C) 2013 S. Karger AG, Basel

Access to full text and tables of contents, including tentative ones for forthcoming issues: www.karger.com/goi_issues 
139 Two Cases of Malignant Struma Ovarii with Metastasis to Pelvic Bone

Steinman, R.A.; De Castro, I.O. (Rochester, N.Y.); Shrayyef, M. (Moncton, N.B./Halifax, N.S./St. John, Nfld.); Chengazi, V.; Giampoli, E.; Van Der Sloot, P.; Calvi, L.M.; Wittlin, S.D.; Hammes, S.R.; Hou, R. (Rochester, N.Y.)

125 Erratum

No. 3

Review

145 Controversies of the Hormonal Conservative Treatment of Endometrial Cancer

Minig, L. (Madrid); Franchi, D. (Milan); Valero de Bernabé, J. (Madrid); Sideri, M. (Milan)

Original Articles

152 The Use of a New Gel Foam for the Evaluation of Tubal Patency Van Schoubroeck, D.; Van den Bosch, T.; Meuleman, C.; Tomassetti, C.; D'Hooghe, T.; Timmerman, D. (Leuven)

157 Ovarian Tissue Cryopreservation by Vitrification in Olive Baboons (Papio anubis): A Pilot Study

Nyachieo, A. (Leuven/Nairobi); Spiessens, C. (Leuven); Chai, D.C.; Kiulia, N.M. (Nairobi); Willemen, D. (Leuven); Mwenda, J.M. (Nairobi); Bourgain, C. (Brussels); D’Hooghe, T.M. (Leuven/Nairobi)

163 Appropriate Cone Dimensions to Achieve Negative Excision Margins after Large Loop Excision of Transformation Zone in the Uterine Cervix for Cervical Intraepithelial Neoplasia Papoutsis, D.; Rodolakis, A.; Mesogitis, S.; Sotiropoulou, M.; Antsaklis, A. (Athens)

169 HIV-1 Seroprevalence among Pregnant Women in Rural Uganda: A Longitudinal Study over Fifteen Years

Reuschel, E. (Regensburg); Tibananuka, S. (Hoima); Seelbach-Goebel, B. (Regensburg)

175 Prophylactic Administration of Cefazolin Prior to Skin Incision versus Antibiotics at Cord Clamping in Preventing Postcesarean Infectious Morbidity: A Systematic Review and Meta-Analysis of Randomized Controlled Trials

Sun, J. (Linyi); Ding, M. (Linyi/Chongqing); Liu, J.; Li, Y.; Sun, X.; Liu, T.; Chen, Y.; Liu, J. (Linyi)

179 Effects of Sex Steroids on Serum Sclerostin Levels during the Menstrual Cycle

Cidem, M.; Usta, T.A.; Karacan, I.; Kucuk, S.H.; Uludag, M.; Gun, K. (Istanbul)

185 Gene Expression Patterns of Insulin-Like Growth Factor 2 in Human Uterine Fibroid Tissues: A Genetic Study with Clinical Correlations

Csatlós, É.; Rigó Jr., J.; Laky, M.; Joó, J.G. (Budapest)

191 Endometrial Thickness in 1,500 Asymptomatic Postmenopausal Women Not on Hormone Replacement Therapy

Hartman, A. (Thornhill, Ont.); Wolfman, W. (Toronto, Ont.); Nayot, D. (Montreal, Que.); Hartman, M. (St. John's, Nfld.)

196 Is Hepcidin a New Cardiovascular Risk Marker in Polycystic Ovary Syndrome?

Gözdemir, E. (Çorum); Kaygusuz, I.; Kafalı, H. (Ankara)

203 Serum Levels of Visfatin and Possible Interaction with Iron Parameters in Gestational Diabetes Mellitus

Kaygusuz, I.; Gumus, I.I.; Yllmaz, S. (Ankara); Simavll, S. (Bolu); Uysal, S. (Ankara); Derbent, A.U. (Antalya); Gözdemir, E. (Çorum); Kafalı, H. (Ankara)

210 Temporal Trend in the Frequency of Ectopic Pregnancies in Lombardy, Italy

Parazzini, F.; Ricci, E.; Cipriani, S.; Chiaffarino, F. (Milano); Chiantera, V. (Berlin); Bulfoni, G. (Milano)
Letter to the Editor

215 Can Female Genital Cosmetic Surgery Be Considered or Classified as Female Genital Mutilation Type IV? Reply to: A. Ostrzenski: Vaginal rugation rejuvenation (restoration): a new surgical technique for an acquired sensation of wide/smooth vagina. Gynecol Obstet Invest 2012;73:48-52. A Rebuttal Puppo, V. (Bologna)

No. 4

Review

217 Placental Mesenchymal Dysplasia: Chronological Observation of Placental Images during Gestation and Review of the Literature

Ohira, S.; Ookubo, N.; Tanaka, K.; Takatsu, A.; Kobara, H.; Kikuchi, N.; Ohya, A.; Kanai, M.; Shiozawa, T. (Matsumoto)

Original Articles

224 What Do Male Medical Students Know about the Pill? Study of Knowledge and Attitudes at the University of Belgrade Gazibara, T.; Trajkovic, G.; Kurtagic, I.; Kovacevic, N.; Nurkovic, S.; Kisic-Tepavcevic, D.; Pekmezovic, T. (Belgrade)

230 Solifenacin Succinate versus Percutaneous Tibial Nerve Stimulation in Women with Overactive Bladder Syndrome: Results of a Randomized Controlled Crossover Study Vecchioli-Scaldazza, C.; Morosetti, C.; Berouz, A.; Giannubilo, W.; Ferrara, V. (Jesi)

235 Genistein Inhibits Cell Proliferation and Stimulates Apoptosis in Human Coronary Artery Endothelial Cells

Kayisli, U.A.; Guzeloglu-Kayisli, O. (New Haven, Conn./Columbus, Ohio); Guzel, E. (New Haven, Conn./Istanbul); Arici, A. (New Haven, Conn.)

243 Spontaneous Perforation of Pyometra: A Report of Seven Cases and Review of the Literature Ikeda, M.; Takahashi, T.; Kurachi, H. (Yamagata)

250 Laparoscopic Adnexectomy with Peritonectomy for an Ovarian Tumor Adhered to the Pelvic Sidewall Kobayashi, E. (Osaka); Kanao, H.; Andou, M. (Kurashiki)

255 Efficacy and Safety of Desvenlafaxine Treatment for Hot Flashes Associated with Menopause: A Meta-Analysis of Randomized Controlled Trials Sun, Z:; Hao, Y.; Zhang, M. (Taian)

263 Prognostic Significance of Serum Soluble CD163 Level in Patients with Epithelial Ovarian Cancer No, J.H.; Moon, J.M.; Kim, K.; Kim, Y.-B. (Seongnam)

268 Kisspeptin, Leptin, and Retinol-Binding Protein 4 in Women with Polycystic Ovary Syndrome Jeon, Y.E.; Lee, K.E.; Jung, J.A.; Yim, S.Y. (Seoul); Kim, H. (Yongin); Seo, S.K.; Cho, S.; Choi, Y.S.; Lee, B.S. (Seoul)

275 Attitudes and Compliance with Research Requirements in Ob/Gyn Residencies: A National Survey

Oakley, S.H.; Crisp, C.C.; Estanol, M.V.; Fellner, A.N.; Kleeman, S.D.; Pauls, R.N. (Cincinnati, Ohio)

281 Effect of Caffeic Acid Phenethyl Ester on Intra-Abdominal Adhesion in Rats

Turgut, A.; Sak, M.E.; Turkcu, G.; Ozler, A.; Soydinc, H.E.; Evsen, M.S.; Evliyaoglu, O.; Akdemir, F. (Diyarbakir) 